\title{
If you haven't read his book, you don't know Jack
}

On September 7, Dr. Jack Kevorkian attended his fortieth suicide, a woman with a spinal cord "disorder" that kept her in a wheelchair and in constant pain. Despite police efforts to prevent the suicide, Isabel Correa pushed the button on Kevorkian's machine (the "Mercitron"), thus unleashing a river of thiopental and concentrated potassium chloride into the vein in her arm that the doctor tapped for her, and ended her life.

Correa is the twelfth person to die in Kevorkian's presence since his acquittal in May on charges of assisted suicide, the third time he has been cleared of criminal wrongdoing in a court of law. His recent "rampage" of assisted suicides (as the New York Times called it) suggests that Kevorkian thinks himself beyond the reach of the law. But the law and its enforcers are both unclear about what to do in this case. Many people believe that Kevorkian is doing the right thing, and just as many others consider him a murderer. And a growing number of others believe Kevorkian's cause is just, but lament the fact that he is the person promoting it. Kevorkian would agree. In his mind, physician-assisted suicide is not his ultimate goal; it is merely a step on the path to a new field of medicine with a new set of terms and practices.

The intensely emotional nature of the debate swirling around Kevorkian's conduct has, until now, focused either on the "ethics" of physician-assisted suicide, the admitted outrageousness of Kevorkian's public behavior, or on the mental status of the people whose death he has assisted. But no one has engaged his beliefs. To argue or agree with him about his actions requires meeting him at the level of his convictions. Although these may be difficult to discern, given the circuslike atmosphere surrounding his public appearances, he has made them known.

Kevorkian is at his most candid in a book he calls "my manifesto," the 1991 Prescription: Medicide, The Goodness of Planned Death. "It doesn't make great reading," he recently told a group of journalists at the National Press Club in Washington, ". . . but it's all there." In short, to understand Kevorkian, you have to read his book.

As its author said, Prescription: Medicide is not great reading. Scathing attacks on anyone who disagrees with him, a high

IMAGE
UNAVAILABLE
FOR
COPYRIGHT
REASONS

degree of stridency (which he acknowledges), and gruesome descriptions of executions are a few of the objectionable elements of the book. At least half of the book describes Kevorkian's involvement in a movement to allow condemned prisoners to donate organs or to participate in medical research once they are put to death (the reasons for this emphasis become clear late in the book). However, the book can also be extremely compelling, especially when Kevorkian describes his own convictions.

Kevorkian's main philosophical belief is in the absolute autonomy or selfdetermination of the individual. Thus, any action taken in relation to that individual must bear that autonomy in mind, particularly any actions taken by a physician. So an individual's desire to end his or her life, if "reasonable" (a term Kevorkian does not define, except to say that "reasonableness" depends on the circumstances of the particular patient and moment in time), must be granted by the physician as an obligation of his or her profession. By the same token, desperately ill, dying patients who do not want to end their lives must not be encouraged to do so, much less helped against their will.

Kevorkian draws distinctions between "obligatory" and "optional" suicide, as well as "assisted" and nonassisted suicide (types of obligatory suicide would in- clude the execution of prisoners and cultic practices such as hara-kiri or suttee, types of optional suicide would include physician-assisted suicide and jumping off a bridge). He argues that none of these, all of which fall under "euthanasia," should be considered immoral.

However, all types of suicide would be rendered "more" ethical with a "wellestablished, tightly controlled, and finely honed program of euthanasia," which would prevent "potentially irrational suicide." In other words, efficient, painless tools of suicide, and help in their use, should be provided by medical specialists. Kevorkian calls this practice "medicide" (as opposed to euthanasia, which he would use to denote the termination of life performed by anybody).

Despite conceptual fuzziness, this is not new turf. But Kevorkian goes on, and this constitutes the ultimate goal of his work, as well as the side of him that the press has ignored.

"Death is always negative in our everyday world. It is ultimately a loss - the loss of life - and by definition that is the negativity of detraction. So, euthanasia is and always has been a purely negative concept, no matter how it's done or what qualifying label is put on it. I am trying to persuade society to turn it around into something positive. I believe that death in every category discussed can be merciful and at the same time yield something of real value to the suffering humanity left behind."

To make this shift from negative to positive euthanasia, Kevorkian argues for the establishment of "obitoriums," suicide centers at which medical specialists ("obitiatrists") will not only assist patients to die, but will extract maximum benefit from the death, by removal of usable organs or through medical research on the unconscious, but not yet deceased individual (with the patients' consent).

"The time has come to let medicide extend a comforting hand to those slipping into the valley of death, and to let obitiatry extract from their ebbing vitality the power to illuminate some of its darkest recesses for those who come after them."

It is likely that once this ultimate goal of Dr. Kevorkian becomes more widely known, the intensity of the whirlwind surrounding him will increase dramatically.

FinTAN R. Steele 